\title{
ANALISIS STANDAR PENILAIAN PENDIDIKAN
}

\author{
Ahmad Mustopa $^{\left.a^{*}\right)}$ Jasim $^{a)}$, Hasan Basri ${ }^{a)}$, Ujang Cepi Barlian ${ }^{a)}$ \\ ${ }^{a)}$ UIN Sunan Gunung Djati, Bandung, Indonesia \\ *)e-mail korespondensi: ahmadmustopa@gmail.com
}

riwayat artikel : diterima: 06 November 2020; direvisi: 16 November 2020; disetujui: 06 Desember 2020

\begin{abstract}
Abstrak. Standar Penilaian Pendidikan adalah kriteria mengenai mekanisme, prosedur, dan instrumen penilaian hasil belajar peserta didik. Standar penilaian oleh pendidik menurut BSNP mencakup standar umum, standar perencanaan, standar pelaksanaan, standar pengolahan dan pelaporan hasil penilaian serta standar pemanfaatan hasil penilaian. Masing-masing standar ini memiliki prinsip-prinsip dan kriteria yang ditetapkan oleh BSNP. Sementara itu, penilaian hasil belajar yang dilakukan oleh satuan pendidikan memiliki dua standar pokok yang harus diperhatikan, yaitu: standar penentuan kenaikan kelas dan standar penentian kelulusan.
\end{abstract}

Kata Kunci: Standar Penilaian

\section{STANDARD ANALYSIS OF EDUCATION ASSESSMENT}

\begin{abstract}
Educational Assessment Standards ar ethe criteria regarding mechanisms, the procedures and instruments for assessing student learning outcomes. According to BSNP, the standardized assessment conducted by educators are to include general standards, planning standards, implementation standards, processing and reporting standards for assessment results as well as standards for the use of the assessment results. Each of these standards contained the principles and criteria established by the BSNP. Meanwhile, the assessment of learning outcomes carried out by educational units contains two main standards that must be considered, namely: the standard for determining class promotion and the standard for terminating graduation.
\end{abstract}

Keywords: Assessment Standards

\section{PENDAHULUAN}

Dalam pembukaan Undang-Undang Dasar (UUD) Negara Republik Indonesia Tahun 1945 dinyatakan bahwa salah satu tujuan Negara Republik Indonesia adalah mencerdaskan kehidupan bangsa dan untuk itu setiap waraga negara Indonesia berhak memperoleh pendidikan yang bermutu sesuai dengan minat dan bakat yang dimilikinya tanpa memandang status sosial, ras, etnis, agama, dan gender. Pemerataan dan mutu pendidikan akan membuat warga negara memiliki keterampilan hidup (life skill) sehingga memiliki kemampuan mengenal dan mengatasi masalah diri dan lingkungannya, mendorong tegaknya masyarakat madani dan modern yang dijiwai nilai-nilai Pancasila (Wahyudi, 2010). Undang-undang Sistem Pendidikan Nasional tahun 2003 pada Bab 1 Pasal 1 ayat (1) menjelaskan bahwa pendidikan adalah usaha sadar dan terencana untuk mewujudkan suasana belajar dan proses pembelajaran agar peserta didik secara aktif mengembangkan potensi dirinya untuk memiliki kekuatan spiritual keagamaan, pengendalian diri, kepribadian, kecerdasan, akhlak mulia, serta keterampilan yang diperlukan dirinya, masyarakat, bangsa dan negara. Potensi diri yang dikembangkan diharapkan dapat menjawab setiap permasalahan dan tantangan pada zamannya (Yusuf, (2015).

Evaluasi atau penilaian dalam pendidikan merupakan salah satukomponen kurikulum sehingga evaluasi atau penilaian ini merupakan hal yang sangat penting dan tidak dapat terpisahkan dengan komponen kurikulum lainnya (Warsito, 2016). Evaluasi atau penilaian menjadi penting karena dijadikan Standar Nasional Pendidikan dalam UndangUndangNo 20 Tahun 2003. Agar adanya pemerataan untuk semua peserta didik baik yang berada diperkotaan maupun di daerah dengan adanya standarisasi penilaian agar terwujudnya tujuan pendidikan nasional. Teknologi informasi dan komunikasi berkembang sedemikian cepat dan memegang peran stratregis pada abad 21, ditandai dengan peran besar pengaruh teknologi informasi dan komunikasi dalam berbagai aspek kehidupan umat manusia (Kusaeri, 2012). Itulah sebabnya, abad 21 ini dikenal pula sebagai era informasi. Batas dan sekat antar negara menjadi semakin tidak jelas dan warga negara menyatu dalam warga dunia global, sehingga era sekarang disebut pula sebagai era global. Keberadaan teknologi tersebut telah mengubah cara manusia dalam bertransaksi, membaca, bersenang-senang, berkomunikasi/berbicara, dan termasuk cara dalam belajar (Alimudin, 2014). Keberadaan teknologi tersebut juga memungkinkan semua orang, yang memiliki akses terhadap teknologi ini tentunya, dapat memperoleh informasi apa saja, dari mana saja, dimana saja, kapan saja. Ini artinya, semua orang dapat belajar apa saja, kapan saja, dimana saja, dengan siapa saja, dengan cara apa saja (Barliant, 2020). Pembelajaran lebih bersifat terbuka, fleksibel dan terdistribusi (distributed). 
Untuk memperoleh informasi tentang pencapaian hasil dari proses pembelajaran peserta didik sesuai dengan tujuan yang telah ditetapkan,maka dibutuhkan penilaian hasil belajar (Destiana, Suchyadi, \& Anjaswuri, 2020)

Dabbagh (2007:221) memberikan karakteristik yang harus dimiliki oleh peserta didik pada abad 21 adalah sebagai berikut :

1. Keterampilan belajar sosial, yang meliputi kemampuan mengambil keputusan, berkomunikasi, membangun kepecayaan, dan manajemen konflik yang semuanya itu merupakan komponen penting dari kolaborasi yang efektif.

2. Keterampilan dialogis,(Discursive Skills); keterampilan ini meliputi kemampuan mendiskusikan suatu isu secara kritis, berbagi ide dan argumentasi secara rasional dan logis, bernegosiasi dan menunjukkan keterbukaan (berpikiran positif) terhadap berbagai perspektif yang berbeda

3. Keterampilan evaluasi diri dan kelompok(introspeksi, artinya kemampuan diri untuk akuntabel terhadap segala sesuatu yang dibebankan di pundaknya dan timnya, aktif dan komitmen terhadap aktifitas kelompoknya, bekerja dengan penuh tanggung jawab, saling membantu dan saling mengisi. Dalam hal ini, setiap individu harus memiliki kemampuan berpikir sistemik, sehingga setiap permasalahan dilihat dari berbagai perspektif dan tidak mengkambinghitamkan orang lain.

4. Keterampilan refleksi, ini adalah kemampuan untuk mengambil hikmah/pelajaran dari berbagai hal. Lebih jauh lagi adalah kemampuan untuk melakukan perubahan (membebaskan diri dari status quo), menerima input, masukan dan kritik dari pihak luar, serta memperbaiki diri maupun kelompok secara terus menerus.

\section{METODE PENELITIAN}

Metode penelitian yang digunakan adalah metode kualitatif deskriptif yang bertujuan untuk mendeskripsikan, menjabarkan, dan melakukan analisis standar penilaian pendidikan. Penelitian ini mengandalkan peneliti sebagai instrumen utama. Pengumpulan data dan informasi menggunakan kajian mendalam melalui proses wawancara, observasi, dan studi dokumentasi mengenai gejala, masalah, serta fakta atau realita yang ada pada objek penelitian. Selanjutnya dilakukan proses eksplorasi pemahaman dengan cara mengumpulkan informasi sebanyak mungkin dari informan didukung dengan data observasi dan dokumentasi untuk kemudian dianalisis dan dideskripsikan, sehingga diperoleh interpretasi mendalam.

\section{DAN PEMBAHASAN}

\section{Analisis Standar Penilaian Pendidikan}

Penilaian pendidikan dalam Permenedikbud No. 66 tahan 2013 dalah proses pengumpulan dan pengolahan informasi untuk mengukur pencapaian hasil belajar peserta didik mencakup, penilaian otentik, penilaian diri, penilaian berbasis portofolio, ulangan harian, ulangan tengah semester, ulangan akhir semester, ujian tingkat kompetensi, ujian tingkat mutu kompetensi, ujian nasional dan ujian sekolah/madrasah.. Kemudian dijelaskan lagi dalam Permendikbud no. 23 tahun 2016 sebagai penggantinya, bahwa penilaian adalah proses pengumpulan dan pengolahan informasi untuk mengukur pencapaian hasil belajar peserta didik.

Menurut Permendikbud 23 Tahun2016, Standar Penilaian Penddidikan adalah kriteria mengenai lingkup, tujuan, manfaat, prinsip, mekanisme, prosedur dan instrument penilaian hasil belajar pesrta didik yang digunakan sebgai dasar dalam penilaian hasil belajar perserta didik pada pendidikan dasar dan menengah. Standar penilaian pendidikan tersebut sebagai acuan penilaian bagi pendidik, satuan pendidikan, dan pemerintah pada penedidikan dasar dan menegah.

Standar penilan pendidikan bertujauan untuk menjamain : 1). Perencanaan penilaian pesrta didik sesuai dengan kompetensi yang akan di capai dan berdasarkan prinsip prinsip penilaian, 2). Pelaksanaan penilaian peeerta didik secra professional, terbuka, efektif, efiisen dan sesuai kontek social budaya, dan 3). Pelaporan hasil penilaian peserta didik secara objektif, akuntabel da informatif.

Penilaian pendidikan yang mengacu pada hasil belajar peserta didik harus mengandung prinsip prinsip di bawah ini :

Adapun prinsip-prinsip penilaian yang telah diatur dalam Permendikbud Nomor 23 Tahun 2016 pada Bab IV Pasal 5 sebagai berikut:

1. Sahih, berarti penilaian didasarkan pada data yang mencerminkan kemampuanyangdiukur;

2. Objektif, berarti penilaian didasarkan pada prosedur dan criteria yang jelas, tidak dipengaruhi subjektivitas penilai;

3. Adil, berarti penilaian tidak menguntungkan atau merugikan peserta didik karena berkebutuhan khusus serta perbedaan latar belakang agama, suku, budaya, adat istiadat, status sosial ekonomi, dan gender.

4. Terpadu, berarti penilaian merupakan salah satu komponen yang tak terpisahkan dari kegiatan pembelajaran;

5. Terbuka, berarti prosedur penilaian, kriteria penilaian, dan dasar pengambilan keputusan dapat diketahui oleh pihak yang berkepentingan;

6. Menyeluruh dan berkesinambungan, berarti penilaian mencakup semua aspek kompetensi dengan menggunakan berbagai teknik penilaian yang sesuai, untuk memantau dan menilai perkembangan kemampuan peserta didik;

7. Sistematis,berarti penilaian dilakukan secara berencana dan bertahap dengan mengikuti langkah-langkah baku;

8. Beracuan kriteria, berarti penilaian didasarkan pada ukuran pencapaian kompetensi yang ditetapkan; dan

9. Akuntabel, berarti penilaian dapat dipertanggungjawabkan, baik dari segi mekanisme, prosedur, teknik, maupun hasilnya

Menururt BNSP ( Badan Standar Nasional Pendidikan ), prinsip prinsip umum penilaian hasil peserta didik anatara

lain : mendidik, transpran, menyeluruh, terpadu dengan pembelajaran objektif, sisitematis, berkesinambungan, adil, dan 
pelaksanaanyamenggunakan acuan kriteria, Penilaian hasil belajar pada pendidikan dasar dan menegah meliputi aspek: 1 ). Sikap, 2). Pengetahuan, 3). Keterampilan. Dalam menilai ranah tersebut maka digunakan penialan otentik, penilaian otentik merupakan penedekatan dan instrument assessment yang memeberikan kesempatan luas kepada peserta didik untuk menerapkan sikap, pengetahuan, dan keterampilan yang sudah di milikinya dalam bentuk tugas.

Peneilaian otentik mengacu pada penilaian kompetensi sikap melalui observsi, penilaian diri, penilaian teman sejawat oleh peserta didik, dan jrnal, Peniaian kompetensi penegtahuan melalui tes tulis, tes lisan, dan penugasan. Serat penilaian Kompetensi keterampilan melaului penilaian kinerja yaiatuu penilaian yang menuntut peserta didik mendemontrasikan suatu kompetensi tertentu dengan menggunakan tes praktik, projek, dan penilan portofolio.Dengan semakin berkembangnya pendidikan, saat ini diharapkan pendidik untuk bisa melakukan pola pendidikan dan pengajaran dngan menegedepankan HPTS ( Higher Order Thinking Skill), yaitu suatu pola pembelajran yang mengaharuskan fasilitator atau oendidik untuk bisa menciptakan interaksi belajar mengajar yang menuntut peserta didik melakukan pola berpikir tingkat tinggi

\section{Standar Penilaian Hasil Belajar oleh Pendidik, Satuan Pendidikan, dan Pemerintah}

Penilaian hasil belajar yang ditetapkan oleh Permendikbud No. 23 Tahun 2016 tentang Standar Penilaian Pendidikan melingkupi penilaian hasil belajar oleh pendidik, penilaian hasil belajar oleh satuan pendidikan, dan penilaian hasil belajar oleh pemerintah. Penilaian hasil belajar oleh pendidik bertujuan untuk memantau dan mengevaluasi proses,kemajuan belajar, dan perbaikan hasil belajar oleh satuan pendidikan bertujuan untuk memantai dan mengevaluasi proses, kemajuan besar, dan perbaikan hasil belajar peserta didik secara berkesinambungan. Penilaian hasil belajar oleh satuan pendidikan bertujuan untuk menilai pencapaian Standar Kompetensi Lulusan untuk semua mata pelajaran. Penilaian hasil belajar oleh pemerintah bertujuan untuk menilai pencapaian kompetensi lulusan secara nasional pada mata pelajaran tertentu.

Standar penilaian oleh pendidik menurut BSNP mencakup : standar umum penilaian, standar perencanaa, standar pelaksanaan, standar pengolahan dna pelaporan hasil penilaian serta standar pemanfaatan hasil penilaian. Masing-masing standar ini memiliki prinsip-prinsip dan kriteria yang ditetapkan oleh BSNP.

\section{a. Bentuk Penilaian}

Penilaian hasil belajar dapat dilakukan dengan menggunakan berbagai bentuk penilaian. Ditinjau dari tekniknya, penilaian dibagi menjadi 2 macam yaitu tes dan non tes. Bentuk penilaian yang dilakukan oleh pendidik, satuan pendidikan, dan pemerintah adalah berbeda.

Tabel 1. Perbedaan bentuk penilaian oleh pendidik, satuan pendidikan, dan pemerintah.

\begin{tabular}{|c|c|c|c|c|c|}
\hline Aspek & & Pendidik & & $\begin{array}{c}\text { Satuan } \\
\text { Pendidikan } \\
\end{array}$ & Pemerintah \\
\hline $\begin{array}{l}\text { Bentuk } \\
\text { penilaian }\end{array}$ & & $\begin{array}{l}\text { Ulangan, } \\
\text { pengamatan, } \\
\text { penugasan, dan/ } \\
\text { atau bentuk lain }\end{array}$ & & $\begin{array}{l}\text { Ujian } \\
\text { sekolah/madrasah }\end{array}$ & $\begin{array}{l}\text { Ujian Nasional dan/ } \\
\text { atau bentuk lain }\end{array}$ \\
\hline Tujuan & 2. & $\begin{array}{l}\text { Mengukur dan } \\
\text { mengetahui } \\
\text { pencapaian } \\
\text { kompetensi peserta } \\
\text { didik } \\
\text { Memperbaiki } \\
\text { proses } \\
\text { pemebelajaran } \\
\text { Menyusun laporan } \\
\text { hasil kemajuan } \\
\text { belajar harian, } \\
\text { tengah semester, } \\
\text { akhir semester } \\
\text { akhir tahun, dan } \\
\text { kenaikan kelas }\end{array}$ & 2. & $\begin{array}{l}\text { Untuk penentuan } \\
\text { kelulusan dari } \\
\text { satuan pendidikan } \\
\text { Melakukan } \\
\text { perbaikan dan } \\
\text { penjaminan mutu } \\
\text { pendidikan }\end{array}$ & $\begin{array}{ll}\text { 1. } & \text { Pemetaaan mutu } \\
\text { program dan satuan } \\
\text { pendidikan } \\
\text { 2. } & \text { Pertimbangan } \\
& \text { seleksi masuk ke } \\
\text { jenjang pendidikan } & \text { berikutnya } \\
\text { 3. } & \text { Pembinaan dan dan } \\
\text { pemberian bantuan } \\
\text { kepada satuan } \\
\text { pendidikan dalam } \\
\text { upayanya } \\
\text { meningkatkan mutu } \\
\text { pendidikan. }\end{array}$ \\
\hline
\end{tabular}

\section{b. Instrumen Penilaian}

Instrumen adalah alat bantu untuk mengumpulkan data atau informasi. Berdasarkan lampiran Permendikbud No. 66 Tahun 2013 tentang standar penilaian pendidikan disebutkan bahwa instrument penilaian harus memenuhi persyaratan: substansi yang mempresentasikan kompetensi yang dinilai, konstruksi yang memenuhi persyaratan teknis sesuai dengan bentuk instrument yang digunakan, dan penggunaan bahasa yang baik dan benar serta komunikatf sesua dengan tingkat perkembangan peserta didik. Berikut adalah tabel instrument penilaian yang digunakan oleh pendidik, satuan pendidikan dan pemerintah: 
Tabel 2 Instrumen Penilaian

\begin{tabular}{lll}
\hline \multicolumn{1}{c}{ Pendidik } & \multicolumn{1}{c}{ Satuan Pendidikan } & \multicolumn{1}{c}{ Pemerintah } \\
\hline Bentuknya berupa tes, & Bentuknya berupa & Bentuknya berupa UN yang \\
pengamatan, penugasan & penilaian akhir atau ujian & memenuhi persyaratan \\
perseorangan atau & sekolah/ madrasah yang & substansi, konstruksi, dan \\
kelompok, dan bentuk & memenuhi persyaratan & bahasa dan memiliki bukti \\
lain yang sesuai dengan & substansi, konstruks, dan & validitas empiric serta \\
karakteristiki & bahasa serta memiliki & menghasilkan skor yang dapat \\
kompetensi dan tingkat & bukti validitas empiric & diperbandingkan antar \\
perkembangan peserta & & sekolah, antardaerah, dan \\
didik & & antartahun. \\
\hline
\end{tabular}

\section{c. Mekanisme Penilaian}

Mekanisme penilaian adalah system/ teori/ upaya yang dilakukan untuk mengukur pencapaian kompetensi peserta didik secara berkelanjutan dalam proses pembelajaran, untuk memantau kemajuan, melakukan perbaikan pembelajaran, dan menentukan keberhasilan belajar peserta didik. Untuk mengukur keberhasilan proses pencapaian kompetensi peserta didik, perlu ditetapkan KKM. Kriteria Ketuntasan Minimal (KKM) adalah kriteria ketuntasan belajar (KKB) yang ditentukan oleh satuan pendidikan.

Mekanisme penilaian hasil belajar pendidik terdapat pada pasal 9 bab VI Permendikbud No. 23 Tahun 2016, yaitu:

1) Perancangan strategi penilaian oleh pendidik dilakukan pada saat penyusunan rencana pelaksanaan pembelajaran (RPP) berdasarkan silabus

2) Penilaian aspek sikap dilakukan melalui oebservasi/pengamatan dan teknik penilaian yang relevan, dan pelaporanya menjadi tanggung jawab wali kelas, atau guru kelas

3) Penilaian aspek pengetahuan dilakukan melalui teks tertulis, tes lisan, dan penugasan sesuia dengan kompetensi yang dinilai

4) Penilaian keterampilan dilakukan melaui praktik, produk proyek portofolio dan/ atau teknik lain sesuian dengan kompetensi yang dinilai

5) Peserta didik yang belum mencapai KKM satuan pendidikan harus mengikuti pembelajaran remidi, dan

6) Hasil penilaian pencapaian kompetensi pengetahuan dan keterampilan peserta didik disampaikan dalm bentuk angka dan/ atau deskripsi.

Mekanisme penilaian hasil belajar oleh satuan pendidikan terdapat pada pasal 10 Bab VI Permendikbud No. 23

Tahun 2016, yaitu:

1) Penetapan KKM yang harus dicapai oleh peserta didik melalui rapat dewan pendidik

2) Penilaian hasil belajar oleh satuan pendidikan pada semua mata pelajaran mencakup aspek sikap, pengetahuan, dan keterampilan

3) Penilaian pada akhir jenjang pendidikan dilakukan melalui ujian sekolah/ madrasah

4) Laporan hasil penilaian pendidikan pada akhir semester dan akhir tahun ditetapkan dalam rapat dewan pendidik berdasarkan hasil penilaian oleh satuan pendidikan dan hasil penilaian oleh pendidik

5) Kenaikan kelas dan kelulusan peserta didik dari satuan pendidikan ditetapkan melaui rapat dewan pendidik

Mekanisme penilaian hasil belajar oleh pemerintah terdapat pada pasal 11 Bab VI Permendikbud NO. 23 Tahun

2016, yaitu:

1) Penilaian hasil belajar oleh pemerintah dilakukan dalam bentuk Ujian Nasional(UN) dan/ atau dalam bentuk lain dalam rangka pengendalian mutu pendidikan

2) Penyelenggaraan UN oleh Badan Standar Nasional Pendidikan (BSNP) bekerjasam dengan instansi terkait untuk megukur pencapaian kompetensi lulusan

3) Hasil UN disampaikan kepada peserta didik dalm bentuk sertifikat hasil UN

4) Hasil UN disampaikan kepad satuan pendidikan untuk dijadikan masukan dalam perbaikan proses pembelajaran

5) Hail UN disampaikan kepada pihak-pihak yang berkepentingan sebagai dasar untuk pemetaan mutu program/ dan / atau satuan pendidikan, pertimbangan seleksi masuk jenjang pendidikan berikutnya, serta pembinaan dan pemberian bantuan kepada satuan pendidikan dalm upanya meningkatkan mutu pendidikan.

6) Bentuk lain penialain haisl belajar oleh pemerintah ddapat dilakukan dalam bentuk survey dan/ atau sensus, dan bentuk lain diatur oleh Peraturan Menteri.

\section{d. Prosedur Penilaian}

Dalam sebuah proses penilaian ada beberapa langkah yang harus ditempuh agar memberikan penilaian yang lebih bermakna dan otentik. Hal ini sangant diperlukan agar hasil dari penilaian dapat dimanfaatkan oleh banyak pihak yang terlibat dalam pendidikan dan berkaiatan dengan objek yang dinilai. Penilaian aspek sikap dilakuakn melalui tahapan: mengamati perilaku peserta didik selama pembelajaran, mencatat perilaku peserta didik dengan menggunkan observasi/ pengamatan, menindaklanjuti hasil pengamtan, dan mendeskripsikan perilaku peserta didik. Penilaian aspek pengetahuan 
dilakukan melalui tahapan: menyusun perencanaan penilaian, mengembangkan instrument penilaian, melaksanakan penilaian, memanfaatkan hasil penilaian dan melaporkan hasil penilaian dalam bentuk angka dengan 0-100 dan deskripsi. Penilaian aspek keterampilan dilakukan melalui tahapan yang sama dengan penilaian aspek pengetahuan.

Dalam pasal 13 Permendikbud no. 23 Tahun 2016 disebutkan bahwa prosedur penilaian proses dan hasil belajar yang dilakukan oleh :

Pendidik :

1) Menetapkan tujuan penilaian dengan mengacu pada RPP yang telah disusun

2) Menyusun kisi-kisi penilaian

3) Membuat instrument penilaian berikut pedoman penilaian

4) Melakukan analisa kualitas instrumen

5) Melakukan penilaian

6) Mengolah, menganalisi, dan menginterpresentasikan hasil penilaian

7) Melaporkan hasil penilaian

8) Memanfaatkan laporan hasil penilaian

Satuan pendidikan:

1) Menetapkan KKM

2) Menyusun kisi-kisi penilaian mata pelajaran

3) Menyususn instrument penilaian dan pedoman penskornya

4) Melakukan analisis kualitas instrument

5) Melakukan penilaian

6) Mengolah, menganalisi,dan menginterpresentasikan hasil penilaian

7) Melaporkan hasil penilaian

8) Memanfaatkan laporan hasil penilaian

Pemerintah:

1) Menyusun kisi-kisi penilaian

2) Menyusun instrument penilitian dan pedoman penskoranya

3) Melakukan analisis kualitas instrument

4) Melakukan penilaian

5) Mengolah, menganalisis, dan menginterpresentasikan hasil penilaian

6) Melaporkan hasil penilaian

7) Memanfaatkan laporan hasil penilaian

Mengingat pentingnya penilaian dalm menentukan kualitas pendidikan maka upaya merencanakan dan melaksanakan penilaian hendaknya memperhatikan beberapa prosedur tersebut. Data hasil penilaian sangat bermanfaat bagi pendidik maupun peserta didik. Demikian juga data hasil penilaian harus dapat ditafsirkan sehingga pendidk dapat memhami peserta didik terutama prestasi dan kemampuan yang dimilikinya. Hasil peniliaian juga hendaknya menjadi bahan untuk menyempurkan program pengajara, memperbaiki kelemahan-kelemahan pengajaran, dan memberikan bimbingan belajar pada peserta didik yang memerlukanya. Lebih jauh lagi dapat dijadikan bahan untuk memperbaik instrument penilaian itu sendiri.

\section{SIMPULAN}

Standar Penilaian merupakan salah satu dari Standar Nasional Pendidikan, sehingga keberadaannya tidak dapat terlepas dari seluruh kegiatan pendidikan. Standar Penilaian Pendidikan adalah kriteria mengenai lingkup, tujuan, manfaat, prinsip, mekanisme, prosedur, dan instrument penilaian hasil belajar peserta didik yang digunakan sebagai dasar dalam penilaian hasil belajar peserta didik pada pendidikan dasar dan pendidikan menengah.Landasan Yuridis Penilaian Pendidikan di Indonesia adalah Undang-Undang Nomor 20 Tahun 2003 tentang Sistem Pendidikan Nasional, yang kemudian diturunkan kedalam Peraturan Pemerintah Nomor 19 Tahun 2005 tentang Standar Nasional Pendidikan yang dirubah kedalam Peraturan Pemerintah Nomor 32 Tahun 2013 dan Peraturan Pemerintah Nomor13 Tahun 2015 tentang Perubahan Kedua atas PP Nomor 19 Tahun 2005 Tentang Standar Nasional Pendidikan. Peraturan Pemerintah tersebut kemudian dijelaskan melalui Peraturan Menteri Pendidikan dan Kebudayaan Republik Indonesia Nomor 23 Tahun 2016 tentang Standar Penilaian Pendidikan. Dari peraturan yang berlaku, bahwa Penilaian Pendidikan Dasar dan Menengah dilakukan oleh Pendidik, Satuan Pendidik, dan oleh Pemerintah. Sedangkan aspek yang dinilai adalah aspek sikap (yang terdiri dari sikap spiritual dan sosial), aspek pengetahuan dan aspek keterampilan. Adapun bentuk dan instrument penilaian dari masing-masing aspek berbeda. Hasil penilaian aspek sikap berupa kualitatif deskripsi, sedangkan aspek pengetahuan dan keterampilan berupa kuantitatif deskripsi. 


\section{REFERENSI}

Alimudin, Penilaian dalam Kurikulum (2013), Proceding SeminarNasional UCP, Vol 1 No 12014

Arifin, Zaenal, (2009) Evaluasi Pembelajaran; Prinsip, Teknik, Prosedur, Bandung: Remaja Rosdakarya, 2009.

Barliant, C Ujang, (2020) Analisis Kebijakan dan Pengelolaan Pendidikan Dasar, Bandung

B. Uno,Hamzah danSatria Koni,(2012.) Assesment Pembelajaran, Jakarta: Bumi Aksara,

Destiana, D., Suchyadi, Y., \& Anjaswuri, F. (2020). Pengembangan instrumen penilaian untuk meningkatkan kualitas pembelajaran produktif di sekolah dasar. Jurnal Pendidikan \& Pengajaran Guru Sekolah Dasar (JPPGuseda), 03(September), 119-123. Retrieved from https://journal.unpak.ac.id/index.php/jppguseda/article/view/2720

Direktorat Pembinaan Sekolah Dasar (2016.) Panduan Penilaian Pendidikan oleh Pendidik dan Satuan Pendidikan Sekolah Dasar, Jakarta: Kementerian Pendidikan dan Kebudayaan,

Direktorat Pembinaan Sekolah Menengah Pertama (2016.) Panduan Penilaian Pendidikan oleh Pendidikdan Satuan Pendidikan Sekolah Menengah Pertama, Jakarta: Kementerian Pendidikan dan Kebudayaa.

Kusaeri dan Supranoto, (2012). Pengukuran dan Penilaian Pendidikan, Yogyakarta: Grahallmu, 2012.

Peraturan Menteri Pendidikan dan Kebudayaan Republik Indonesia Nomor 23 Tahun 2016 tentang Standar Penilaian Pendidikan.

Peraturan Menteri Pendidikan dan Kebudayaan Republik Indonesia No53 Tahun 2013 tentang Penilaian Hasil Belajar oleh Pendidik dan Satuan Pendidikan pada Pendidikan Dasar dan Menengah.

Peraturan Menteri Riset, Teknologi, dan Pendidikan Tinggi Republik Indonesia Nomor 44 Tahun 2015 tentang Standar Nasional Pendidikan Tinggi.

Wahyudi, (2010) Asesmen Pembelajaran Berbasis Portofolio diSekolah, Jurnal Visi Ilmu Pendidikan, Vol 2, No 1 Januari 2010

Warsito Hadi, (2016). Kritik Penilaian Menurut Prespektif Standar Nasional Pendidikan, dalam ElBanat: Jurnal Pemikiran dan Pendidikan Islam, Volume 6 Nomor 2, Juli - Desember 2016.

Yusuf,A. Muri, (2015) Asesmendan Evaluasi Pendidikan; Pilar Penyedia Informasi dan Kegiatan Pengendalian Mutu Pendidikan,Jakarta: Kencana. 